\title{
A New Radical Scavenging Anthracene Glycoside, Asperflavin Ribofuranoside, and Polyketides from a Marine Isolate of the Fungus Microsporum
}

\author{
Yong Li,${ }^{a}$ Xifeng Li, ${ }^{a}$ Uk LeE, ${ }^{a}$ Jung Sook KAnG,${ }^{b}$ Hong Dae CHOI, ${ }^{c}$ and Byeng Wha Son $*, a$ \\ ${ }^{a}$ Department of Chemistry, Pukyong National University; Busan 608-737, Korea: ${ }^{b}$ College of Dentistry, Pusan National \\ University; Busan 602-739, Korea: and ${ }^{c}$ Department of Chemistry, Dongeui University; Busan 614-714, Korea. \\ Received April 28, 2005; accepted March 7, 2006
}

A new anthracene glycoside, asperflavin ribofuranoside (1), and the previously described polyketides, flavoglaucin (2), isodihydroauroglaucin (3), and citrinin (4) have been isolated from the marine-derived fungus Microsporum sp. The structure and absolute stereochemistry of a new compound (1) was assigned on the basis of physicochemical data. Compounds $1-3$ exhibited a significant radical scavenging activity against 1,1-diphenyl2-picrylhydrazyl (DPPH) with $\mathrm{IC}_{50}$ values of 14.2, 11.3, and $11.5 \mu \mathrm{M}$, respectively, which are more potent than the positive control, ascorbic acid $\left(\mathrm{IC}_{50}, 20 \mu \mathrm{M}\right)$. Compound 1 also showed a moderate antibacterial activity against the methicillin-resistant and multidrug-resistant Staphylococcus aureus (MRSA and MDRSA) with MIC value of $50 \mu \mathrm{g} / \mathrm{ml}$. activity

Key words Microsporum sp.; asperflavin ribofuranoside; flavoglaucin; isodihydroauroglaucin; citrinin; radical scavenging

As part of an effort to discover biologically active natural products from marine microorganisms, ${ }^{1)}$ we have investigated bioactive constituents from the marine-derived algicolous fungus Microsporum sp. and isolated a new asperflavin ribofuranoside (1), as well as three known polyketides, flavoglaucin (2), ${ }^{2)}$ isodihydroauroglaucin $\left.(3),{ }^{3}\right)$ and citrinin (4). ${ }^{4)}$ This paper briefly describes the isolation of $\mathbf{1}-\mathbf{4}$, structure elucidation of $\mathbf{1}$, and evaluation of $\mathbf{1}-\mathbf{4}$ for their radical scavenging and antibacterial activities.

The broth and mycelium extracts were found to show a radical scavenging activity against 1,1-diphenyl-2-picrylhydrazyl (DPPH). So, the both extracts were combined and separated by bioassay-guided fractionation using silica vacuum flash and HPLC methods to yield the asperflavin ribofuranoside (1), flavoglaucin (2), isodihydroauroglaucin (3), and citrinin (4).

Asperflavin ribofuranoside $(\mathbf{1}),[\alpha]_{\mathrm{D}}+23.8^{\circ} \quad(c=0.2$, $\mathrm{MeOH}$ ), was isolated as a yellow oil, which was deduced to have the molecular formula $\mathrm{C}_{21} \mathrm{H}_{24} \mathrm{O}_{9}$ from the high resolution (HR)-FAB-MS and ${ }^{13} \mathrm{C}-\mathrm{NMR}$ data. The IR spectrum of 1 suggested the presence of hydroxyl $\left(3429 \mathrm{~cm}^{-1}\right)$, conjugated enone $\left(1632 \mathrm{~cm}^{-1}\right)$, aryl $\left(1605 \mathrm{~cm}^{-1}\right)$, and glycosidic $\left(1045 \mathrm{~cm}^{-1}\right)$ groups.

Detailed analyses of the ${ }^{1} \mathrm{H}-$ and ${ }^{13} \mathrm{C}-\mathrm{NMR}$ data of $\mathbf{1}$

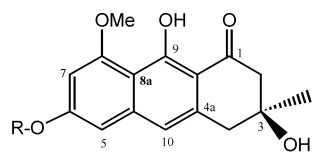

asperflavin ribofuranoside (1): $\mathrm{R}=a$-D-ribofuranose asperflavin (1a): $\mathrm{R}=\mathrm{H}$

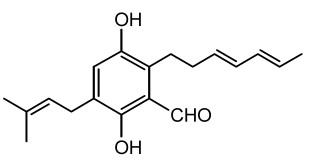

isodihydroauroglaucin (3)<smiles>CCCCCc1c(O)cc(CC=C(C)C)c(O)c1O</smiles>

flavoglaucin (2)

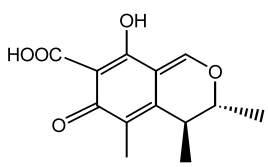

citrinin (4)

* To whom correspondence should be addressed. e-mail: sonbw@pknu.ac.kr

revealed the presence of eight $s p^{2}$ and one $s p^{3}$ quaternary carbons, three $s p^{2}$ methines, four $s p^{3}$ oxymethines, one oxymethylene, two methylenes, one oxymethyl, and one methyl (Table 1). Extensive analysis of 2D NMR spectra, correlated spectroscopy (COSY), ${ }^{1} \mathrm{H}$-detected heteronuclear multiple-quantum coherence (HMQC), heteronuclear multple-bond correlation (HMBC), and nuclear Overhauser enhanced and exchange spectroscopy (NOESY), suggested that 1 was a glycoside which consisted of a dihydroanthracenone

Table 1. NMR Data for Asperflavin Ribofuranoside (1)

\begin{tabular}{|c|c|c|c|}
\hline Position & $\delta_{\mathrm{H}}($ mult.,,$J)$ & $\delta_{\mathrm{C}}$ (mult.) & HMBC \\
\hline 1 & & $203.7(\mathrm{~s})$ & \\
\hline 2 & $\begin{array}{l}2.64(\mathrm{~d}, 17.0) \\
2.86(\mathrm{~d}, 17.0)\end{array}$ & $51.5(\mathrm{t})$ & $1,3,4,9 \mathrm{a}, 3-\mathrm{CH}_{3}$ \\
\hline 3 & & $69.4(\mathrm{~s})$ & \\
\hline $3-\mathrm{CH}_{3}$ & $1.27(\mathrm{~s})$ & $28.8(q)$ & $2,3,4$ \\
\hline 4 & $\begin{array}{l}2.91(\mathrm{~d}, 16.3) \\
3.02(\mathrm{~d}, 16.3)\end{array}$ & $42.7(\mathrm{t})$ & $2,3,4 a, 9 a, 10$ \\
\hline $4 a$ & & $138.1(\mathrm{~s})$ & \\
\hline 5 & $6.84(\mathrm{~d}, 2.0)$ & $102.2(\mathrm{~d})$ & $6,7,8 \mathrm{a}, 10$ \\
\hline 6 & & $159.4(\mathrm{~s})$ & \\
\hline 7 & $6.58(\mathrm{~d}, 2.0)$ & 98.7 (d) & $5,6,8,8 \mathrm{a}$ \\
\hline 8 & & $160.6(\mathrm{~s})$ & \\
\hline $8-\mathrm{OCH}_{3}$ & $3.87(\mathrm{~s})$ & $55.8(q)$ & 8 \\
\hline $8 \mathrm{a}$ & & $109.6(\mathrm{~s})^{b)}$ & \\
\hline 9 & & $164.5(\mathrm{~s})$ & \\
\hline $9 \mathrm{a}$ & & $109.5(\mathrm{~s})^{b)}$ & \\
\hline 10 & $6.91(\mathrm{~s})$ & $116.5(\mathrm{~d})$ & $4,5,8 \mathrm{a}, 9 \mathrm{a}, 10 \mathrm{a}$ \\
\hline $10 \mathrm{a}$ & & $141.0(\mathrm{~s})$ & \\
\hline $3-\mathrm{OH}$ & $4.85(\mathrm{~s})$ & & $2,3,3-\mathrm{CH}_{3}$ \\
\hline 9-OH & $14.87(\mathrm{~s})$ & & $8 \mathrm{a}, 9,9 \mathrm{a}$ \\
\hline $1^{\prime}$ & $5.75(\mathrm{~d}, 4.5)$ & 99.9 (d) & $6,3^{\prime}, 4^{\prime}$ \\
\hline $2^{\prime}$ & $4.11(\mathrm{~m})$ & $71.5(d)$ & $1^{\prime}, 3^{\prime}$ \\
\hline $3^{\prime}$ & $3.95(\mathrm{~m})$ & 69.2 (d) & $1^{\prime}, 2^{\prime}, 5^{\prime}$ \\
\hline $4^{\prime}$ & $4.01(\mathrm{~m})$ & 86.5 (d) & \\
\hline $5^{\prime}$ & $3.49(\mathrm{~m})$ & $61.5(\mathrm{t})$ & $3^{\prime}$ \\
\hline $2^{\prime}-\mathrm{OH}$ & $4.75(\mathrm{~d}, 8.8)$ & & $2^{\prime}$ \\
\hline $3^{\prime}-\mathrm{OH}$ & $4.93(\mathrm{~d}, 5.3)$ & & $2^{\prime}, 3^{\prime}, 4^{\prime}$ \\
\hline $5^{\prime}-\mathrm{OH}$ & $4.82(\mathrm{t}, 5.6)$ & & $4^{\prime}, 5^{\prime}$ \\
\hline
\end{tabular}

a) Recorded in DMSO at $400 \mathrm{MHz}\left({ }^{1} \mathrm{H}\right)$ and $100 \mathrm{MHz}\left({ }^{13} \mathrm{C}\right)$. b) Exchangeable 
derivative as aglycone and one sugar unit.

Acid hydrolysis of $\mathbf{1}$ furnished asperflavin (1a), $[\alpha]_{\mathrm{D}}$ $+8.8^{\circ}(c=0.3, \mathrm{MeOH}),{ }^{5)}$ and methyl sugar, which was identified as ribose on the basis of GC-MS analysis of the trimethylsilyl derivative. Key HMBC correlation from $\mathrm{H}-1^{\prime}$ to $\mathrm{C}-6$ in $\mathbf{1}$ was critical in establishing the position of ribose attached at $\mathrm{C}-6$.

The stereochemistry of the anomeric position of the sugar moiety was assigned as $\alpha$-configuration on the basis of chemical shifts and coupling constant at $\mathrm{C}-1[\delta 5.75(\mathrm{~d}$, $J=4.5 \mathrm{~Hz}$ ), 99.9 (d)] and the comparison of ${ }^{13} \mathrm{C}-\mathrm{NMR}$ data of ribofuranose moiety with the reported value. ${ }^{6}$

The absolute configuration of the ribose unit was determined as $\mathrm{D}$ from the optical rotation of the tetraacetate derived from ribose. The specific rotation of ribose tetraacetate, $[\alpha]_{\mathrm{D}}-55.2^{\circ}(c=0.5, \mathrm{MeOH})$, which was obtained from acid hydrolysis of 1 with $9 \%$ aq. $\mathrm{HCl}$, indicated the presence of Dribose in $\mathbf{1}^{7,8)}$

From all of these results the structure of asperflavin ribofuranoside was deduced as $(+)-6-O$ - $(\alpha$-D-ribofuranosyl $)-3,4-$ dihydro-3,6,9-trihydroxy-8-methoxy-3-methylanthracen$1(2 H)$-one (1).

Compounds $\mathbf{1}-\mathbf{4}$ exhibited a radical scavenging activity against DPPH with $\mathrm{IC}_{50}$ values of $14.2,11.3,11.5$ and $48.5 \mu \mathrm{M}$, respectively. Among them, $\mathbf{1}-\mathbf{3}$ were more potent than the positive control, ascorbic acid $\left(\mathrm{IC}_{50}, 20 \mu \mathrm{M}\right)$.

Compound 1 also showed a moderate antibacterial activity against the methicillin-resistant and multidrug-resistant Staphylococcus aureus with MIC values of $50.0 \mu \mathrm{g} / \mathrm{ml}$, respectively.

\section{Experimental}

General The instruments used to obtain the physical data were the same as those described in our previous paper. ${ }^{9)}$

Fungal Isolation and Culture The fungal strain, Microsporum sp., was isolated from the surface of the marine red alga Lomentaria catenata collected at the Golmae Village, Ulsan City, Korea in 2004, and identified based on the morphological evaluation and on the fatty acid methyl ester analysis (Korean Culture Center of Microorganisms, Seoul, Korea; similarity index 0.62). A voucher specimen is deposited at Pukyong National University with the code MFA212-1. The fungus was cultured (201) for $30 \mathrm{~d}$ (static) at $29^{\circ} \mathrm{C}$ in SWS medium: soytone $(0.1 \%)$, soluble starch $(1.0 \%)$, and seawater $(100 \%)$

Extraction and Isolation The culture broth and mycelium were separated, and the resulted broth and mycelium were extracted with ethyl acetate and $\mathrm{CH}_{2} \mathrm{Cl}_{2}-\mathrm{MeOH}(1: 1)$ to provide the broth extract $(800 \mathrm{mg})$ and the mycelium extract $(600 \mathrm{mg})$, respectively. Both extracts were combined, and the total extract $(1.4 \mathrm{~g})$ was fractionated by silica gel flash chromatography ( $n$-hexane/EtOAc) to generate four fractions containing compounds $\mathbf{1 - 4}$, respectively. Final purification of the each fractions by ODS column chromatography $\left(\mathrm{H}_{2} \mathrm{O}\right.$ in $\left.\mathrm{MeOH}\right)$, followed by HPLC (YMC ODS-A, $\mathrm{MeOH}$ ), yielded the asperflavin ribofuranoside $(\mathbf{1}, 7.0 \mathrm{mg})$, flavoglaucin $(\mathbf{2}, 19.0 \mathrm{mg})$, isodihydroauroglaucin $(3,5.0 \mathrm{mg})$, and citrinin $(4,12.0 \mathrm{mg})$, respectively.

Asperflavin Ribofuranoside (1): Yellow oil; $[\alpha]_{\mathrm{D}}^{20}+23.8^{\circ} \quad(c=0.2$, $\mathrm{MeOH}$ ); IR (neat) $v_{\max } 3429,2921,2853,2360,2341,1632,1605,1432$, $1383,1330,1289,1245,1201,1167,1113,1045,1017,827,667 \mathrm{~cm}^{-1}$; UV $(\mathrm{MeOH}) \lambda_{\max }(\log \varepsilon) 225$ (0.91), 269 (1.22), $312(0.44), 388$ (0.62) nm; LRFAB-MS $m / z$ 421.01 [M+H] ${ }^{+}$, HR-FAB-MS $m / z 421.4265[\mathrm{M}+\mathrm{H}]^{+}$(Calcd for $\mathrm{C}_{21} \mathrm{H}_{25} \mathrm{O}_{9}, 421.4257$ ); see Table 1 for NMR spectral data.

Compounds $2-4$ showed spectral data virtually identical to those reported in the literature. ${ }^{2-4)}$

Acid Hydrolysis of 1, and Sugar Analysis A solution of $\mathbf{1}(10 \mathrm{mg})$ in $9 \%$ dry methanolic $\mathrm{HCl}(0.5 \mathrm{ml})$ was stirred at r.t. for $3 \mathrm{~h}\left(\mathrm{~N}_{2}\right.$ atmosphere). The reaction mixture was neutralized with $\mathrm{Ag}_{2} \mathrm{CO}_{3}$ and filtrated. The residue, obtained by removal of the solvent, was purified by $\mathrm{Si}$ gel $\left(\mathrm{CH}_{2} \mathrm{Cl}_{2}-\mathrm{MeOH}=10: 1\right)$, and then with HPLC (ODS-A, MeOH) to furnish an aglycone $(6 \mathrm{mg})$, which was identical to asperflavin (1a) ${ }^{5)}$ and methyl ribofuranoside fraction $(2 \mathrm{mg})$

The sugar fraction was dissolved in pyridine $(0.5 \mathrm{ml})$ and treated with bis(trimethylsilyl)trifluoroacetamide (BSTFA) $(0.5 \mathrm{ml})$ at r.t. for $30 \mathrm{~min}$. Solvent was removed by a nitrogen stream and the residue dissolved in hexane was used for GC-MS analysis [(DB-1MS column, $60 \mathrm{~m} \times 0.32 \mathrm{~mm}$ ); $\mathrm{N}_{2}$ as a carrier gas at $0.7 \mathrm{ml} / \mathrm{min}$; the program rate: $80-260^{\circ} \mathrm{C}$ at $5{ }^{\circ} \mathrm{C} / \mathrm{min}$ ] showing peak at $t_{\mathrm{R}} 19.54 \mathrm{~min}$, which corresponded to those of TMS/Me derivative of ribose $\left(\mathrm{m} / \mathrm{z} 380[\mathrm{M}]^{+}\right)$.

Determination of the Stereochemistry of the Ribofuranose A solution of $1(14.7 \mathrm{mg})$ in $9 \%$ aq. $\mathrm{HCl}(10 \mathrm{ml})$ was stirred at $80^{\circ} \mathrm{C}$ for $1 \mathrm{~h}$. The reaction mixture was treated as described above, and the residue thus obtained was partitioned into $\mathrm{H}_{2} \mathrm{O}$ and $\mathrm{CH}_{2} \mathrm{Cl}_{2}$ to give the organic phase and the aqueous phase. Acetylation of the aqueous portion $(10 \mathrm{mg})$, obtained after removal of the solvent under reduced pressure, in the usual manner (acetic anhydride-pyridine) furnished the ribose tetraacetate $(11.6 \mathrm{mg})$. The rotation recorded for ribose tetraacetate isolated in this study was $[\alpha]_{\mathrm{D}}$ $-55.2^{\circ}(c=0.5, \mathrm{MeOH})$, which showed D-ribose in 1 (lit. $-55.4^{\circ}$ in D-ribose; $+55.2^{\circ}$ in L-ribose) $)^{7,8)}$

Ribose tetraacetate: $[\alpha]_{\mathrm{D}}-55.2^{\circ}(c=0.5, \mathrm{MeOH}) ;{ }^{1} \mathrm{H}-\mathrm{NMR}(400 \mathrm{MHz}$ $\left.\mathrm{CDCl}_{3}\right) \delta: 6.01(1 \mathrm{H}, \mathrm{d}, J=4.8 \mathrm{~Hz}, \mathrm{H}-1), 5.02(1 \mathrm{H}, \mathrm{dd}, J=4.8,3.7 \mathrm{~Hz}, \mathrm{H}-2)$ $5.47(1 \mathrm{H}, \mathrm{dd}, J=3.7,3.2 \mathrm{~Hz}, \mathrm{H}-3), 5.14(1 \mathrm{H}$, ddd, $J=4.3,3.2,3.2 \mathrm{~Hz}, \mathrm{H}-4)$, $3.90\left(1 \mathrm{H}, \mathrm{dd}, J=12.3,4.3 \mathrm{~Hz}, \mathrm{H}_{\mathrm{a}}-5\right), 4.01\left(1 \mathrm{H}, \mathrm{dd}, J=12.3,3.2 \mathrm{~Hz}, \mathrm{H}_{\mathrm{b}}-5\right)$ 2.12, 2.09, 2.08, and 2.07 (each $3 \mathrm{H}, \mathrm{s}, \mathrm{Ac}) ;{ }^{13} \mathrm{C}-\mathrm{NMR}\left(100 \mathrm{MHz}, \mathrm{CDCl}_{3}\right) \delta$ : 90.8 (d, C-1), 67.2 (d, C-2), 66.1 (d, C-3), 66.2 (d, C-4), 62.6 (t, C-5), 169.8, 169.7, 169.4, and 168.7 (each s, Ac), 20.6, 20.6, 20.7, and 20.8 (each q, Ac).

Radical Scavenging Assay ${ }^{10}$ Samples to be tested were dissolved in $\mathrm{MeOH}$ and the solution $(160 \mu \mathrm{l})$ was dispensed into wells of a 96-well microtiter tray. Fourty microliters of the DPPH solution in $\mathrm{MeOH}$ $\left(1.5 \times 10^{-4} \mathrm{M}\right)$ was added to each well. The mixture was shaken and left to stand for $30 \mathrm{~min}$, and the absorbance of the resulting solution was measured at $520 \mathrm{~nm}$ with microplate reader (Packard Co., Spectra Count ${ }^{\mathrm{TM}}$ ). The scavenging activity on DPPH radical was expressed as $\mathrm{IC}_{50}$, which is the concentration of the tested compound required to give a $50 \%$ decrease of the absorbance from that of the blank solution [consisting of $\mathrm{MeOH}(160 \mu \mathrm{l})$ and DPPH solution $(40 \mu \mathrm{l})]$

Antibacterial Assay ${ }^{11)}$ The in vitro antibiotic activity in extracts and purification samples were evaluated by the conventional a 2-fold serial dilution method using $S$. aureus, methicillin-resistant $S$. aureus, and multidurgresistant $S$. aureus as an indicator strain. A $5-\mathrm{ml}$ suspension containing $10^{5}$ cells per $\mathrm{ml}$ was used as inoculum of the test organism. The MIC values were determined after the inoculation for $18 \mathrm{~h}$ at $37^{\circ} \mathrm{C}$.

Acknowledgements Y.L. and X.L. acknowledge the support of the Brain Korea 21 (BK21) (F020). Circular dichroism (CD) and Mass spectral data were kindly provided by the Korea Basic Science Institute. This work was supported by MarineBio21 (Ministry of Maritime Affairs and Fisheries, Korea).

\section{References}

1) Li X., Kim M. K., Lee U., Kim S.-K., Kang J. S., Choi H. D., Son B. W., Chem. Pharm. Bull., 53, 453- 455 (2005).

2) Hamasaki T., Fukunaga M., Kimura Y., Hatsuda Y., Agric. Biol. Chem., 44, 1685-1687 (1980).

3) Hamasaki T., Kimura Y., Hatsuda Y., Nagao M., Agric. Biol. Chem., 45, 313-314 (1981).

4) "Handbook of Toxic Fungal Metabolites," ed. by Cole R. J., Cox R. H. Academic Press, New York, 1981, pp. 824-829.

5) Fujimoto H., Fujimaki T., Okuyama E., Yamazaki M., Chem. Pharm Bull., 47, 1426-1432 (1999), and references cited therein.

6) "Structure Determination of Organic Compounds, Tables of Spectral Data," ed. by Pretsch E., Buhlmann P., Affolter C., Springer, New York, 2000, p. 152.

7) Zinner H., Chem. Ber, 86, 817 (1953).

8) Jung M. E., Xu Y., Tetrahedron Lett., 38, 4199- 4202 (1997).

9) Li X., Lee S. M., Choi H. D., Kang J. S., Son B. W., Chem. Pharm. Bull., 51, 1458-1459 (2003).

10) Li X. F., Li Y., Nam K. W., Kim D.-S., Choi H. D., Son B. W., Kor. $J$ Pharmacogn., 33, 219-223 (2002).

11) Li Y., Li X., Son B. W., Choi H. D., Kor. J. Pharmacogn., 34, 142144 (2003). 